
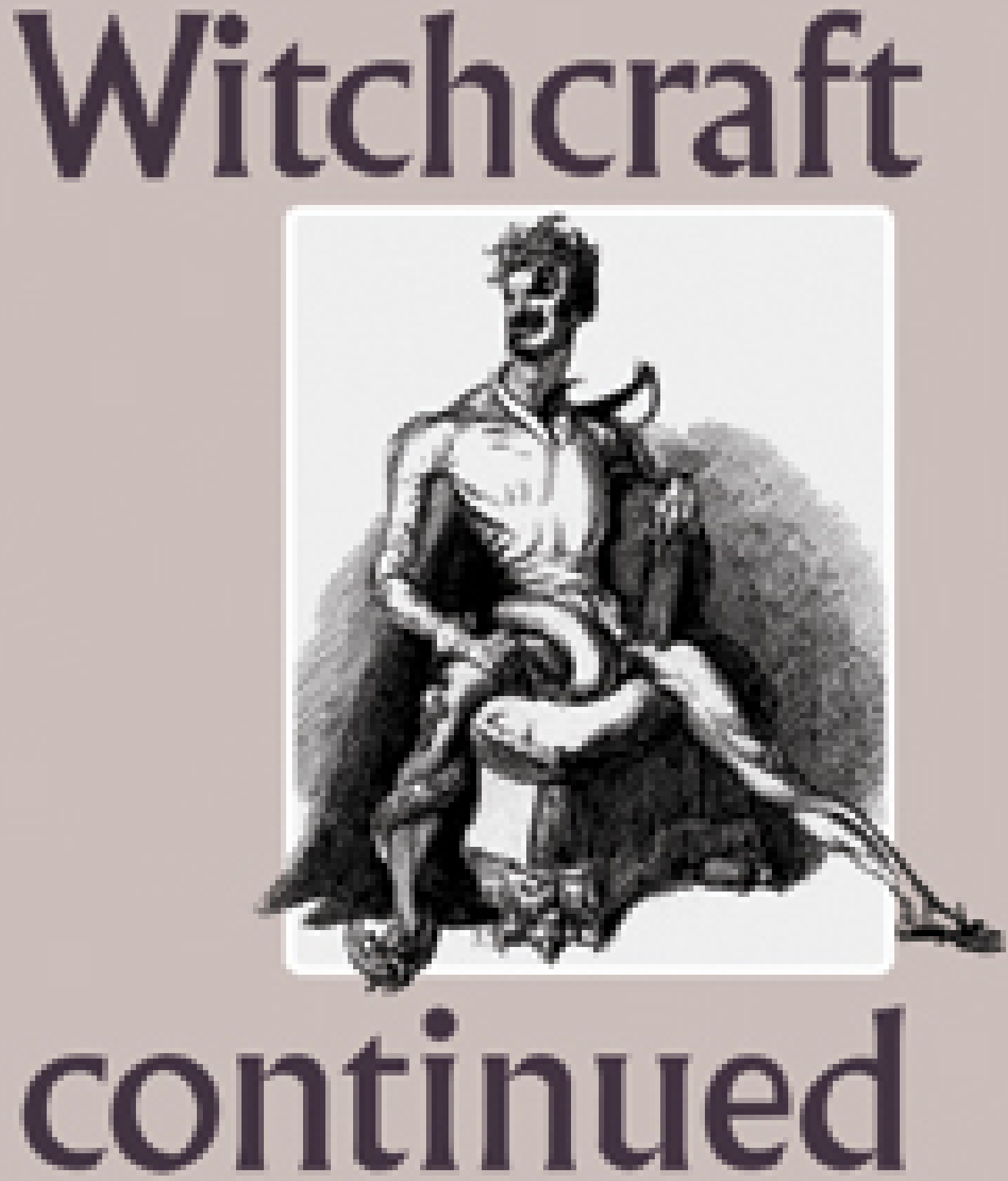

Popular mage in modern Europe

ahis

WILLE DE BLÉCOURT \& OWEN DAVIES 


\section{WITCHCRAFT CONTINUED}


Willem de Blécourt and Owen Davies - 9781526137975 Downloaded from manchesterhive.com at 04/26/2023 ०3: $03: 50 \mathrm{PM}$ via free access 


\section{WITCHCRAFT CONTINUED}

\section{Popular magic in modern Europe}

edited by

Willem de Blécourt and Owen Davies

Manchester University Press

Manchester 
Copyright (C) Manchester University Press 2004

While copyright in the volume as a whole is vested in Manchester University Press, copyright in individual chapters belongs to their respective authors.

This electronic version has been made freely available under a Creative Commons (CC-BY-NC-ND) licence, which permits non-commercial use, distribution and reproduction provided the author(s) and Manchester University Press are fully cited and no modifications or adaptations are made. Details of the licence can be viewed at https://creativecommons.org/licenses/by-nc-nd/3.0/

Published by Manchester University Press Oxford Road, Manchester M13 9NR, UK

and Room 400, 175 Fifth Avenue, New York, NY 10010, USA

www.manchesteruniversitypress.co.uk

British Library Cataloguing-in-Publication Data

A catalogue record for this book is available from the British Library

Library of Congress Cataloging-in-Publication Data applied for

ISBN 0719066581 hardback

EAN 9780719066580

ISBN O $71906659 \times$ paperback

EAN 9780719066597

First published 2004

$\begin{array}{llllllllllllllllllll}13 & 12 & 11 & 10 & 09 & 08 & 07 & 06 & 05 & 04 & 10 & 9 & 8 & 7 & 6 & 5 & 4 & 3 & 2 & 1\end{array}$

Typeset in Monotype Bell by

Carnegie Publishing Ltd, Lancaster 